\title{
The Effect of Repeat Annual Applications of Prohexadione-calcium on Fruit Set, Return Bloom, and Fruit Size of Apples
}

\author{
Duane W. Greene ${ }^{1}$ \\ Department of Plant, Soil and Insect Sciences, University of Massachusetts, \\ Bowditch Hall, Amherst, MA 01003
}

Additional index words. Apogee, Regalis, flowering, fruit size, crop load

\begin{abstract}
Prohexadione-calcium (ProCa) is used routinely in orchards to control vegetative growth and to reduce the shoot blight phase of fire blight. This communication reports on multiple-year applications of ProCa with special emphasis on treatment effects on fruit set, fruit size, and return bloom. Increased fruit set was confirmed from high rates of ProCa above $125 \mathrm{mg} \cdot \mathrm{L}^{-1}$. The increase in fruit set was attributed primarily to a reduction of abscission during June drop rather than an increase in initial set. ProCa decreased fruit weight in some instances. Part of this reduction could be attributed to increased fruit set. However, the large reduction in fruit weight at harvest could only be explained by a direct effect of ProCa when used at high rates. When ProCa was applied as a concentrate spray at $250 \mathrm{mg} \cdot \mathrm{L}^{-1}$, terminal growth was reduced comparable to the application made as a tree row volume dilute spray $(1 \times)$. However, fruit set was increased when the spray volume in which ProCa was delivered was reduced to $4 \times$. A range of ProCa rates was used on 'Mutsu'. An initial application rate of $42 \mathrm{mg} \cdot \mathrm{L}^{-1}$ followed by similar subsequent rates controlled growth comparably to higher initial and total rates, yet low rates had no effect on fruit weight or return bloom. Low rates of ProCa appear to be effective at controlling vegetative growth yet appear to have minimal side effects. High rates, especially those intended to reduce fire blight, come with the risk of increased fruit set and reduced fruit size and return bloom.
\end{abstract}

Prohexadione-calcium (ProCa) has emerged as the primary plant growth regulator used to control vegetative growth on apples (Basak, 2004; Byers et al., 2004; Greene, 1999; Medjdoub et al., 2005; Miller, 2002; Rademacher and Kober, 2003; Unrath, 1999). It is also very effective in the control of fire blight in the shoot phase of this disease (Buban et al., 2004; Norelli and Miller, 2004; Rademacher, 2004; Rademacher and Kober, 2003; Yoder et al., 1999). The timings for the first application of ProCa to retard vegetative growth and to control fire blight are the same. The first application is made when terminal shoot growth is between 2 and $7 \mathrm{~cm}$ and this timing generally coincides with early petal fall (Greene, 1999; Rademacher, 2004). It is important to make the initial application at this growth stage because shoot growth is very rapid at this time and there is a lag time of 10 to $14 \mathrm{~d}$ for ProCa to start to initially inhibit terminal shoot growth (Greene and Autio, 2002). Application at an earlier time, although desirable, may be less effective because there is insufficient foliage to absorb the ProCa, and if applied during bloom, petals may interfere with thorough coverage of the emerging leaves.

Received for publication 24 July 2007. Accepted for publication 16 Nov. 2007.

${ }^{1}$ To whom reprint requests should be addressed; e-mail dgreene@pssci.umass.edu.
ProCa may increase fruit set and cause a tree to retain more fruit than on nontreated trees (Byers et al., 2004; Glenn and Miller, 2005; Greene, 1999). A more aggressive thinning program may be required to adequately reduce crop load on ProCa-treated trees (Cooley, 2007). These thinning strategies generally include increased dosage of thinners or multiple thinner applications. The increase in fruit set after ProCa application is well documented (Glenn and Miller, 2005; Greene, 1999, 2007; Medjdoub et al., 2005). The effect of ProCa on growth control from this initial application can last up to 5 to 6 weeks after the initial application. Because initial fruit set and June drop occur over this time period, ProCa may increase fruit set by increasing initial set, decreasing June drop, or a combination of both. How ProCa increases fruit set has not yet been resolved, although it appears that higher initial rates are associated with the greatest increase in fruit set (Greene, 2007; Miller, 2007).

There have been many reports on the effectiveness, timing, and rate of ProCa on growth control, fruit set, and return bloom (Byers and Yoder, 1999; Costa et al., 2000; Medjdoub et al., 2005; Miller, 2002). However, these reports are based primarily on application made in 1 year and observations made during just one fruiting cycle. Applications made in sequential years have the potential to change spur structure, which may affect flowering and fruit set in subsequent years. To date, there have been no reports to document effects of ProCa made on the same trees for more than 1 year.

The ProCa (Apogee) label (BASF Corporation, 2007) provides information on how to calculate the amount of ProCa to apply to a block of trees based on a volume [tree row volume dilute (TRV)] that is necessary for a dilute application. Once the application rate is determined, the label suggests that ProCa may be applied in a convenient and reduced amount of water, but this leads to the possibility of applying very high concentrations as a result of the concentration effect. There have been no studies that have reported the effects of ProCa being applied as a concentrate spray, especially when these treatments have been repeated.

This study was initiated in an attempt to answer several questions. The first objective was to determine if ProCa was applied in multiple years had any incremental or confounding effect that had not been reported in the previous studies in which ProCa was applied in just 1 year. A second objective was to determine if ProCa applied as a concentrate spray differed from application made as a dilute spray. The final objective was to determine if the increase in fruit set caused by ProCa was a result of an increase in initial set, a reduction in June drop, or a combination of both.

\section{Materials and Methods}

General. All trees used in this investigation were growing at the University of Massachusetts Horticultural Research Center, Belchertown, MA. Cultural practices and pest management were carried out using accepted commercial practices. All trees in this investigation received chemical thinning sprays deemed appropriate for the situation. All ProCa sprays contained $0.1 \%$ (v/v) Regulaid surfactant (Kalo, Overland Park, KS) and $2.5 \mathrm{~mL} \cdot \mathrm{L}^{-1}$ Quest water conditioner (a proprietary water conditioner blend of ammonium salts of polyacrylic, hydroxycarboxylic, and phosphoric acids; Helena Chemical Co., Collierville, $\mathrm{TN}$ ) Control trees received no spray.

Expt. 1: Prohexadione-calcium concentration, 'Mutsu'. A block of mature 'Mutsu'/ M.7 apple trees was selected for treatment. Twenty-five trees were selected at bloom time and blocked into five groups (replications) of five trees each based on rated blossom cluster density. On 10 May 2002 when average shoot length was $6.1 \mathrm{~cm}$, one tree in each block was sprayed with ProCa at $42,83,125$, or $250 \mathrm{mg} \cdot \mathrm{L}^{-1}$. Sprays were applied at a TRV rate of $2337 \mathrm{~L} \cdot \mathrm{ha}^{-1}(250 \mathrm{gal} /$ acre) using a commercial tractor-mounted airblast sprayer. Repeat applications of ProCa with additives were made on 24 May, 2 July, and 18 July for a total dose at the end of the season of $0,167,208,229$, and $416 \mathrm{mg} \cdot \mathrm{L}^{-1}$ for treatments $1,2,3,4$, and 5, respectively. At the end of June drop in July, two limbs per tree 10 to $15 \mathrm{~cm}$ in circumference were selected on each tree and all 
persisting fruit counted. At the normal time of harvest in October, 25 fruit per tree were randomly harvested from the periphery of the tree and weighed. Twenty shoots were randomly selected from the periphery of the tree and their length measured after leaf drop in November.

At the pink stage of flower development in April 2003 and 2004, two limbs per tree 10 to $15 \mathrm{~cm}$ in circumference were selected from each tree. Usually, but not always, limbs used the previous years were selected. All blossom clusters on the tagged limbs were counted. On 16 May 2003 and 14 May 2004 when terminal shoot growth averaged $9.6 \mathrm{~cm}$ and $9.8 \mathrm{~cm}$, respectively, ProCa was applied to the same trees at $42,83,125$, or $250 \mathrm{mg} \cdot \mathrm{L}^{-1}$ with $0.1 \%$ Regulaid and $2.5 \mathrm{~mL} \cdot \mathrm{L}^{-1}$ Quest at a TRV of $2337 \mathrm{~L} \cdot \mathrm{ha}^{-1}$ as previously described. Repeat applications were made on 30 May and 30 June 2003 to give a total of 0,126 , 208,313 , and $563 \mathrm{mg} \cdot \mathrm{L}^{-1}$ that was applied. Final fruit set was taken at the end of June drop in July of both years. A 25-apple sample was taken in 2003 and 2004 at normal harvest and weighed. Terminal growth on 20 randomly selected shoots on the periphery of each tree was taken in Nov. 2003.

Expt. 2: Prohexadione-calcium concentrate volume, 'McIntosh'. A block of mature 'McIntosh'/M.7 trees were selected and blocked into seven groups (replications) of four trees each based on rated bloom density. On 17 May 2002 when shoot growth averaged $7.9 \mathrm{~cm}$, one tree in each block was sprayed with $250 \mathrm{mg} \cdot \mathrm{L}^{-1}$ ProCa containing $0.1 \%$ Regulaid and $2.5 \mathrm{~mL} \cdot \mathrm{L}^{-1}$ Quest water conditioner using a commercial airblast sprayer at a TRV dilute rate of $1870 \mathrm{~L} \cdot \mathrm{ha}^{-1}$ (200 gal/acre). Another tree in each block was sprayed with ProCa at $500 \mathrm{mg} \cdot \mathrm{L}^{-1}$ in 935 $\mathrm{L} \cdot \mathrm{ha}^{-1}(100 \mathrm{gal} / \mathrm{acre})$ and a third tree received $1000 \mathrm{mg} \cdot \mathrm{L}^{-1}$ ProCa applied at $468 \mathrm{~L} \cdot \mathrm{ha}^{-1}(50$ gal/acre). A fourth tree in each block was not sprayed and served as the untreated control. Two weeks later on 31 May, all trees receiving ProCa were sprayed again with half the amount of ProCa in the spray volumes initially received. At the end of June drop in July, two limbs per tree 10 to $15 \mathrm{~cm}$ in circumference were tagged, measured, and then all persisting fruit counted. At the normal harvest time in September, 25 fruit per tree were randomly harvested from the periphery of the tree and weighed. Final terminal growth was determined in November by measuring the length of 20 randomly selected terminal shoots from each tree.

At the pink stage of flower development in April 2003, two limbs per tree 10 to $15 \mathrm{~cm}$ in circumference were tagged and all blossom clusters were counted. Petal fall treatments that were applied the previous year were again applied on the same trees on 19 May using the same concentrations, volumes of water, and spray additives. A repeat application as described in 2002 using half the amount of ProCa was applied on 6 June. Fruit set, fruit weight, and terminal growth were determined as described for 2002. Return bloom was determined in April 2004 on limbs previously tagged and measured in 2003.

Expt. 3: Prohexadione-calcium initial set, 'McIntosh'. In a block of mature 'McIntosh'/M.9, 16 trees were selected for this experiment. At the pink stage of flower development, two limbs per tree 10 to 12 $\mathrm{cm}$ in circumference were tagged. All blossom clusters were counted on the limbs. Trees were blocked into eight groups (replications) of two trees each based on the calculated blossom clusters per centimeter limb cross-sectional area. One tree in each group was designated to receive ProCa, whereas the second tree received no spray and was designated the untreated control. On 10 May 2002, when terminal shoot growth averaged $4.0 \mathrm{~cm}$, one tree in each block received a dilute handgun application of ProCa at $250 \mathrm{mg} \cdot \mathrm{L}^{-1}$ containing $0.1 \%$ Regulaid surfactant $(\mathrm{v} / \mathrm{v})$ and $2.5 \mathrm{~mL} \cdot \mathrm{L}^{-1}$ Quest water conditioner. Treated trees received repeat handgun applications of ProCa at 125 $\mathrm{mg} \cdot \mathrm{L}^{-1}$ with surfactant and water conditioner on 28 May and 18 July. On 29 May, initial fruit set counts were taken on all tagged limbs and fruit size measurements were taken on 30 randomly selected fruit per tree. At the end of June drop in July, all persisting fruit were counted on tagged limbs. At the normal harvest time in September, 20 fruit per tree were harvested randomly from the periphery of each tree and average fruit weight determined. Terminal shoot growth was taken on 15 randomly selected shoots per tree after leaf fall in November.

In 2003, the initial application of ProCa at $250 \mathrm{mg} \cdot \mathrm{L}^{-1}$ was made on 16 May when terminal growth averaged $5.4 \mathrm{~cm}$ and in 2004, the initial spray was applied on 14 May when terminal growth averaged $6.1 \mathrm{~cm}$. Initial set on tagged limbs and fruit size on 30 fruit per tree were taken in 2004 on 27 May, $13 \mathrm{~d}$ after the initial ProCa application. No initial set was taken in 2003 because there was a large difference in return bloom between control and ProCa-treated trees. Repeat applications of ProCa at $125 \mathrm{mg} \cdot \mathrm{L}^{-1}$ were made on 30 May 2003 and 6 June 2004. Spray application and methods for collection of bloom, initial set, final set, fruit size, and final terminal growth were similar to that described in 2002 .

Statistical analysis. Statistical analysis was done using analysis of variance to determine significance of treatments. When appropriate, means were separated by regression analysis when the control was considered a zero level of ProCa.

\section{Results}

Expt. 1: Prohexadione-calcium concentration, 'Mutsu'. Application of ProCa to 'Mutsu' apple trees at initial rates of 42 to $250 \mathrm{mg} \cdot \mathrm{L}^{-1}$ did not result in increased fruit set at the normally accepted level of $P=0.05$ level, although it was significant at the $P=$ 0.09 level (Table 1$)$. There was a highly significant linear reduction in fruit weight with increasing concentration. Terminal growth was reduced somewhat comparably with all
ProCa treatments. Return bloom in 2003 was significantly reduced, especially at the higher ProCa rates. Similar to the previous year, fruit set was unaffected by ProCa treatments at the $P=0.05$ level, but it was at the $P=0.08$ level. Fruit weight in 2003 was reduced linearly with increasing ProCa rate and terminal growth was reduced somewhat comparably with all ProCa treatments. In 2004, no treatment influenced return bloom or fruit set, but fruit weight was significantly reduced.

Expt. 2: Prohexadione-calcium concentrate volume, 'McIntosh'. When ProCa was applied in 2002 at a rate of $250 \mathrm{mg} \cdot \mathrm{L}^{-1}$ in a volume ranging from TRV dilute to $4 \times$, there was a linear increase in fruit set on 'McIntosh' apples (Table 2). Fruit size was modestly reduced and terminal growth was comparably and appropriately reduced by the ProCa treatments regardless of concentration. There was a linear reduction in return bloom with increasing level of concentration and an increase in fruit set in 2003. Fruit set in all treatments was within the generally accepted range of five to seven fruit per centimeter limb cross-sectional area (LCSA). There was a highly significant reduction in fruit weight and terminal growth in 2003 and a reduction in return bloom in 2004 as a result of treatments applied in 2003. Because the reduction in both fruit weight and terminal growth was a quadratic response to volume in both 2002 and 2003, this is interpreted to mean that there was no concentrate response for either of these parameters.

Expt. 3: Prohexadione-calcium initial set, 'McIntosh'. When ProCa was applied in 2002 at the commercially recommended timing of petal fall, neither initial set nor fruit size was affected 19 d later (Table 3). However, fruit set was more than doubled on ProCa-treated trees when final set was taken in July. There was a highly significant reduction in fruit weight and terminal growth cause by ProCa. Return bloom was significantly reduced in 2003, and as a result of the dramatic reduction in bloom, there was also a reduction in final fruit set when expressed as fruit per centimeter LCSA. Fruit weight and terminal growth were reduced in 2003. ProCa did not influence return bloom or initial set in 2004 , although there was a small yet significant reduction in fruit size when measured $13 \mathrm{~d}$ after the initial application of ProCa. Fruit weight and terminal growth were reduced in 2004 as a result of the one initial application of ProCa at petal fall.

\section{Discussion}

The fruit set and return bloom problems associated with ProCa use were generally associated with high rates (Cooley, 2007). Consequently, the rates used in this investigation were chosen to enhance the probability of documenting a response. All rates were within ProCa label restrictions for both initial amount applied and the total amount applied in any one season. However, the rates normally recommended for vegetative growth control would be less than rates used here 
Table 1. Effect of prohexadione-calcium (ProCa) on bloom, fruit set, fruit weight, and terminal growth of Mutsu/M.7 Expt. 1.

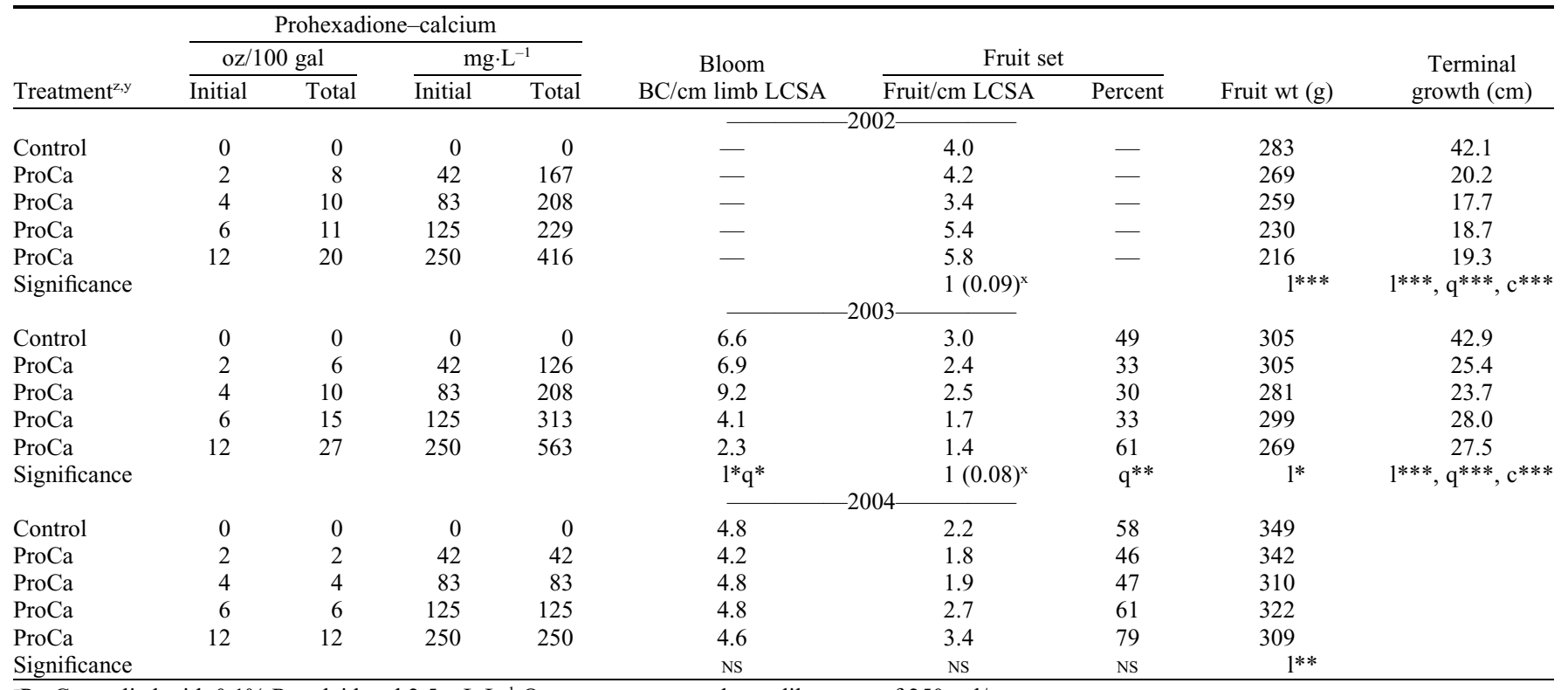

${ }^{2}$ ProCa applied with $0.1 \%$ Regulaid and $2.5 \mathrm{~mL} \cdot \mathrm{L}^{-1}$ Quest at tree row volume dilute rate of $250 \mathrm{gal} / \mathrm{acre}$.

${ }^{y}$ Treatments applied 10 May, 24 May, 2 July, and 18 July 2002; 16 May, 30 May, and 30 June 2003; and 14 May 2004.

${ }^{\mathrm{x}}$ Numbers in parentheses indicate level of significance.

Ns, ${ }^{*}, * *, * * *$ Nonsignificant or significant at $P=0.05,0.01$, or 0.001 , respectively. $1, \mathrm{q}$, or c indicates that significance is linear, quadratic, or cubic, respectively.

$\mathrm{BC}=$ blossom clusters; LCSA $=$ limb cross-sectional area.

Table 2. Effect of applying prohexadione-calcium (ProCa) in different spray volumes on bloom, fruit set, fruit weight and terminal growth of McIntosh/M.7 Expt. 2.

\begin{tabular}{|c|c|c|c|c|c|c|c|}
\hline \multirow[b]{2}{*}{ Treatment ${ }^{z, y}$} & \multirow[b]{2}{*}{ Volume } & \multirow{2}{*}{$\begin{array}{l}\text { ProCa concn. } \\
\text { in tank } \\
\left(\mathrm{mg} \cdot \mathrm{L}^{-1}\right) \\
\end{array}$} & \multirow{2}{*}{$\begin{array}{l}\text { Bloom } \\
\mathrm{BC} / \mathrm{cm} \\
\mathrm{LCSA} \\
\end{array}$} & \multicolumn{2}{|c|}{ Fruit set } & \multirow[b]{2}{*}{$\begin{array}{l}\text { Fruit } \\
\text { wt (g) }\end{array}$} & \multirow[b]{2}{*}{$\begin{array}{c}\text { Terminal } \\
\text { growth }(\mathrm{cm})\end{array}$} \\
\hline & & & & $\begin{array}{c}\text { Fruit/cm } \\
\text { LCSA }\end{array}$ & Percent & & \\
\hline & & & & -2002 & - & & \\
\hline Control & - & - & - & 2.6 & - & 179 & 46.7 \\
\hline ProCa & $1 \times$ & 250 & - & 3.0 & - & 170 & 23.4 \\
\hline ProCa & $2 x$ & 500 & - & 2.8 & - & 164 & 22.5 \\
\hline ProCa & $4 \times$ & 1000 & - & 4.2 & - & 172 & 23.3 \\
\hline Significance & & & & $\begin{array}{l}1 * * * \\
-2003\end{array}$ & & $\mathrm{q}^{*}$ & $1^{* * *}, \mathrm{q}^{* * * *}$ \\
\hline Control & - & - & 11.6 & 5.8 & 49 & 146 & 38.8 \\
\hline ProCa & $1 \times$ & 250 & 8.4 & 7.3 & 91 & 120 & 22.1 \\
\hline ProCa & $2 \times$ & 500 & 7.3 & 8.0 & 94 & 114 & 20.3 \\
\hline ProCa & $4 \times$ & 1000 & 7.1 & 6.1 & 92 & 125 & 22.6 \\
\hline Significance & & & $1 * * *$ & $\begin{array}{c}\mathrm{q}^{*} \\
-2004\end{array}$ & $1^{* * *}, \mathrm{q}^{* *}$ & $1^{* * *}, \mathrm{q}^{* * *}$ & $1^{* * *}, \mathrm{q}^{* * *}$ \\
\hline Control & - & - & 13.6 & & & & \\
\hline ProCa & $1 \times$ & 250 & 7.1 & & & & \\
\hline ProCa & $2 \times$ & 500 & 7.1 & & & & \\
\hline ProCa & $4 \times$ & 1000 & 5.2 & & & & \\
\hline Significance & & & $1 * * *$, & & & & \\
\hline
\end{tabular}

with the exception of lower rates that were used on 'Mutsu'.

It is a widely acknowledged pomological principal that there is an inverse relationship between fruit set and return bloom. There were also observations made in some commercial orchards that suggest that ProCa may reduce return bloom that appears to be independent of fruit set (Cooley, 2007). In this investigation, there are several pieces of evidence to support this observation. In Expt. 1 on 'Mutsu', ProCa did not increase fruit set in Year 1, yet return bloom the next year was significantly reduced. In Expt. 2, ProCa did increase fruit set the first 2 years albeit to a moderate extent, but return bloom was more adversely affected than one might reasonably expect from the same level of fruit set. A high rate of ProCa was used on 'McIntosh' in Expt. 3. Set was increased in Year 1, which resulted in a large reduction in both bloom and fruit set the next year. In the third year of the experiment, there was no effect of any treatment on return bloom, whereas ProCatreated trees had significantly reduced fruit set the previous year.
It is generally acknowledged that there is an inverse relationship between fruit set and fruit size. In the instances in which ProCa is reported to increase fruit set, there is also a reduction in fruit size. Miller (2007) has made the observation that there appears to be instances in which ProCa did reduce fruit size in the absence of any observable increase in fruit set. In this investigation, 'Mutsu' trees were treated and fruit set was taken over a 3 -year period. In no year did ProCa increase fruit set at $P=0.05$, although significance was documented in Years 1 and 2 at $P=0.09$ and $P=0.08$, respectively. In all 3 years, ProCa reduced fruit size ( 1 year at $P=0.001$ and 2 years at $P=0.01)$. In Expt. 3, fruit set on ProCa-treated trees was significantly lower than on control trees in Year 2, attributable in large part to reduced return bloom. In this year, the weight of fruit harvested from treated trees was significantly reduced.

ProCa can substantially increase yield while reducing fruit size (Greene, 1999). Under some circumstances, this reduction in fruit size may be viewed as a positive effect of ProCa. Large-fruited cultivars such as 'Mutsu' used in this experiment may benefit from a reduction in fruit size. This, coupled with the increase in fruit set, may lead to increased crop value.

High initial fruit set has the potential to reduce fruit size. This may be partially attributed to the intense competition among fruit for photosynthates as fruit reach the 7- to $10-\mathrm{mm}$ stage of fruit development (Lakso et al., 1998). In this investigation, initial set and fruit size in Expt. 3 was taken for 2 years on 'McIntosh'. In Year 1, ProCa had no influence on either initial set or initial fruit size. In the second year, initial set was unaffected by treatment, but there was a 
Table 3. Effect of prohexadione-calcium (ProCa) on bloom, initial set, fruit set, fruit weight, and terminal growth of McIntosh/M.9 apples.

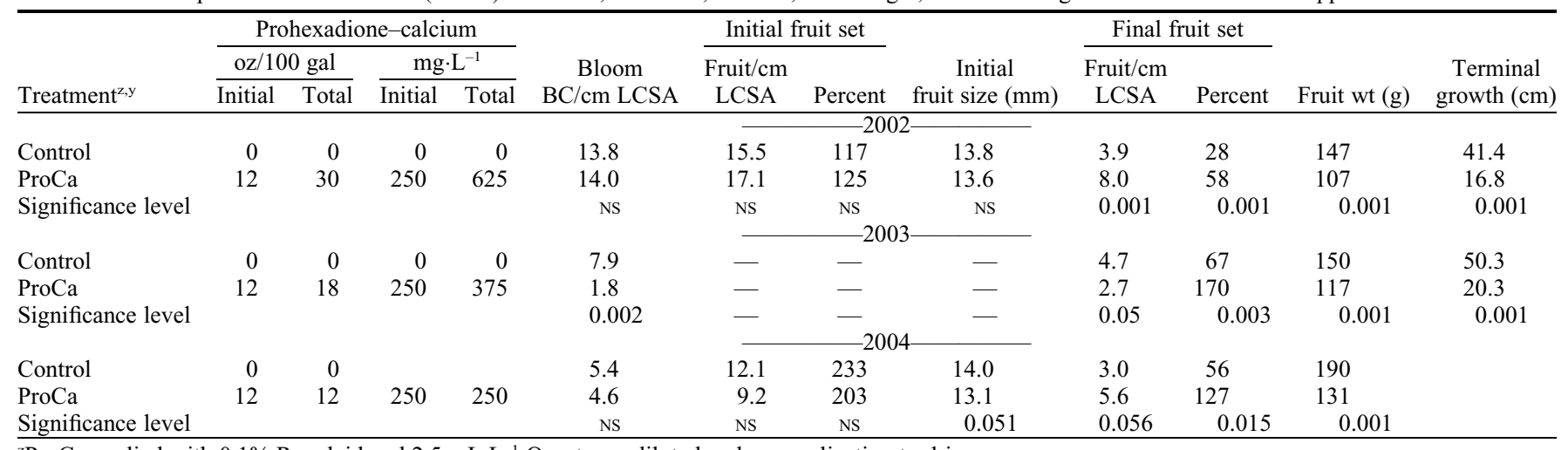

${ }^{2}$ ProCa applied with $0.1 \%$ Regulaid and $2.5 \mathrm{~mL} \cdot \mathrm{L}^{-1}$ Quest as a dilute handgun application to drip.

y Treatments applied 10 May, 28 May, and 18 July 2002; 16 and 30 May 2003; 14 May and 6 June 2004.

$\mathrm{BC}=$ blossom clusters; LCSA $=$ limb cross-sectional area.

Ns Nonsignificant.

small but significant reduction in initial fruit size. In both years, there was a large reduction in fruit weight at harvest. It requires 10 to $14 \mathrm{~d}$ after application for ProCa to start to be effective (Greene, 1999), and this is the approximate time initial set and fruit size was taken on these trees. Therefore, it is not surprising to find that ProCa had little or no effect at this time. Cell division occurs slowly for a period of time after pollination, and then fruit growth and cell division proceed exponentially for at least 3 weeks (Denne, 1963). This period of rapid growth is followed by a period of declining growth and cell division that occurs until $\approx 7$ weeks after pollination (Denne, 1963). Gibberellins are known to stimulate the growth of apple fruit (Bukovac and Nakagawa, 1968). ProCa inhibits gibberellin biosynthesis (Rademacher et al., 1992). Therefore, ProCa may be reducing fruit size primarily by slowing cell division during this active period of cell division in the apple flesh. An alternative or contributing factor reducing fruit size could be reduced leaf area. Although leaf area on spurs and limbs was not evaluated, a reduction in leaf area, which may reduce carbohydrate supply to the developing fruit, could also reduce fruit size.

The range of concentrations of ProCa applied initially as well as the total amount applied were selected to represent the commercial and practical extremes in the amount of ProCa applied for retardation of terminal growth. The lowest initial rate (42 $\mathrm{mg} \cdot \mathrm{L}^{-1}$ ) and the total amount applied (168 to $210 \mathrm{mg} \cdot \mathrm{L}^{-1}$ ) was lower than the lowest recommended rates on the current ProCa (Apogee) label (BASF Corporation, 2007). Growth reduction from the lowest and highest rates applied were comparable, indicating that excellent commercial growth retardation in growth is possible using lower rates. Furthermore, reductions in fruit weight and return bloom were linear with increasing concentration; thus, these consequences may be minimized by using these lower rates. Rademacher and Kober (2003) have similarly suggested using lower rates of ProCa.
Amelioration of complications associated with the use of ProCa for fire blight control may be less promising. Norelli and Miller (2004) reported that increased resistance to fire blight after ProCa application is linearly related to the amount of ProCa applied. Frequently, initial rates of $250 \mathrm{mg} \cdot \mathrm{L}^{-1}$ may be required and are suggested on the ProCa (Apogee) label. Therefore, reduced return bloom and a reduction in fruit size may be a consequence and a price that growers may be required to pay to effectively use ProCa to control fire blight to commercially acceptable levels.

\section{Literature Cited}

Basak, A. 2004. Growth and fruiting of 'Elstar' apple trees in response to prohexadione calcium depending on the rootstock. Acta Hort. 653:117-125.

BASF Corporation. 2007 Apogee plant growth regulator. BASF Corporation, Research Triangle Park, NC.

Buban, T., L. Foldes, Z. Fekete, and W. Rademacher. 2004. Effectiveness of the resistance inducer prohexadione-Ca against fireblight in shoots of apple trees inoculated with Erwinia amylovora. Bulletin OEPP/EPPO Bulletin 34:369-376.

Bukovac, M.J. and S. Nakagawa. 1968. Gibberellin induced asymmetric growth of apple fruit. HortScience 3:172-174.

Byers, R.E., D.H. Carbaugh, and L.D. Combs. 2004. The influence of prohexadione-calcium sprays on apple tree growth, chemical thinning, and return bloom. J. Amer. Pomol. Soc. 58:111-117.

Byers, R.E. and K.S. Yoder. 1999. Prohexadionecalcium inhibits apple, but not peach tree growth, but has little influence on apple fruit thinning or quality. HortScience 34:12051209.

Cooley, D. 2007. 2007 New England tree-fruit pest management guide. University of Massachusetts, Amherst, in collaboration with the Land Grant Universities of New England and Cornell University.

Costa, G., M.C. Andreotti, E. Sabatini, A.M. Bregoli, C. Bomben, and G. Vizzotto. 2000. The effect of prohexadione-Ca on tree growth and fireblight suppression in apple and pear. Proc. 27th Plant Growth Regul. Soc. Amer. 27:253-258.
Denne, M.P. 1963. Fruit development and some tree factors affecting it. N.Z. J. Bot. 1:265-294. Glenn, D.M. and S.S. Miller. 2005. Effect of Apogee on growth and whole-canopy photosynthesis in spur 'Delicious' apples trees. HortScience 40:397-400.

Greene, D.W. 1999. Tree growth management and fruit quality of apple trees treated with prohexadione-calcium (BAS 125). HortScience 40:397-400.

Greene, D.W. 2007. The effect of prohexadionecalcium on fruit set and chemical thinning of apple trees. HortScience 42:1361-1365.

Greene, D.W. and W.R. Autio. 2002. Apogee ${ }^{\circledR}-$ A new growth retardant for apples. Univ. Mass Ext. Factsheet F-127R.

Lakso, A.N., M. Bepete, M.C. Goffinet, and L.C. Corelli Grappadelli. 1998. Aspects of carbon supply and demand in apple fruits. Acta Hort. 466:13-18.

Medjdoub, R., J. Val, and A. Blanko. 2005. Inhibition of vegetative growth in red apple cultivars using prohexadione-calcium. J. Hort. Sci. Biotechnol. 80:263-271.

Miller, S.S. 2002. Prohexadione-calcium controls vegetative growth in apple. J. Tree Fruit Prod. $3: 11-28$.

Miller, S.S. 2008. Effect of Apogee on fruit set and size. Compact Fruit Tree (in press).

Norelli, J.L. and S.S. Miller. 2004. Effect of prohexadione-calcium dose level on shoot growth and fire blight in young apple trees. Plant Dis. 88:1099-1106.

Rademacher, W. 2004. Prohexadione-Ca induces resistance against fire blight and other diseases. EOPP Bulletin 34:383-388.

Rademacher, W. and R. Kober. 2003. Efficient use of prohexadione- $\mathrm{Ca}$ in pome fruits. Europ. J. Hort. Sci. 68:101-107.

Rademacher, W., K.E. Temple-Smith, D.L. Griggs, and P. Hedden. 1992. The mode of action of acylcyclohexanediones-A new type of growth retardant, p. 571-577. In: Karssen, C.M., L.C. van Loon, and D. Vreugdenhil (eds.). Progress in plant growth regulation. Kluwer Academic, Dordrecht, The Netherlands.

Unrath, C.R. 1999. Prohexadione-Ca: A promising chemical for controlling vegetative growth of apples. HortScience 34:1197-1200.

Yoder, K.S., S.S. Miller, and R.E. Byers. 1999. Suppression of fireblight in apple shoots by prohexadione-calcium following experimental and natural inoculation. HortScience 34:12021204. 